\title{
A study on management of corporate cash in consumer durable sector
}

\author{
Somnath Das*
}

Assistant Professor in Commerce, Rabindra Mahavidyalaya, Champadanga, Hooghly, West-Bengal, (712401), India

\begin{tabular}{l}
\hline C H R O N I C L E \\
\hline Article history: \\
Received September 28, 2014 \\
Accepted 28 December 2014 \\
Available online \\
January 102015 \\
\hline Keywords: \\
Cash Management \\
Treasury Management \\
Cash Conversion Cycle \\
Cash Holding \\
Credit worthiness
\end{tabular}

\section{Introduction}

In modern business world, cash performs various functions, makes it possible the payment by cheque and acts as a storage for earmarked funds. It is a reservoir of money, which could be used to meet emergencies (Bari, 1981). Nowadays, business uses credit instead of cash in its routine work. The use of bills, draft, credit cards, debit cards, ECS, fund transfer through internet etc. replaces the use of coin and paper currency (Bradley, 1974). Sometimes, the term 'cash' refers to the currency plus bank A/C balances held at different commercial banks (Brandt, 1965; Clarkson et al., 1972; Driscoll, 1983).

Cash management is the art and increasingly the science of managing a company's short-term resources to sustain its ongoing activities, mobilizing funds and optimizing liquidity (Kim et al., 1998; Chiou et al., 2006). The most important elements of cash management are - (a) properly management of shortterm assets and liabilities of the organization throughout the life span of the business, (b) properly forecasting and utilization of organization's earnings, payments and balance funds, (c) properly and effectively management of existing funds with the help of available information and also determining

\footnotetext{
*Corresponding author.

E-mail addresses: somnath211@yahoo.co.in (S. Das)

(c) 2015 Growing Science Ltd. All rights reserved. doi: $10.5267 /$ j.msl.2015.1.006
} 
the risk. Due to deficiency of liquid funds or cash, the organization can be liquidated or closed. So, proper management of cash does not mean to protect bankruptcy but also to maintain a desired level of profitability (Ferreira \& Vilela, 2004; Jensen, 1986; Kalcheva \& Lins, 2007).

The need for cash management is generally undergone by the new and growing organizations. Cash flow can be a problem even when a small business has numerous clients, offers a superior product to its customers and enjoys a sterling reputation in its industry. It creates a problem for innovation or expansion (Coyle, 2000). Lack of proper cash flows makes the organization difficult to hire and maintain efficient employees. Apart from that desirable funds, we need to require regular payments of salaries and other expenses. Cash management to some extent is associated with treasury management. Treasury management is known as a set of techniques, which emphasis on the liquidity of a company by affecting the factors and processes which convert immediately into cash with the objective of increasing the profitability and improving the working capital management (Nunn, 1981; Cohen \& Robbins, 1966).

This paper discusses another very important parameter of cash management i.e. Cash Conversion Cycle. The term Cash Conversion Cycle can be considered as a length of time between purchase of raw-materials and collection of cash from debtors. For measuring the efficiency of liquidity management Cash Conversion Cycle can be frequently used. It indicates how efficiently working capital should be managed (Fazzari \& Petersen, 1993; Guney et al., 2007).

Modigliani Miller also opined for holding less amount of cash. In this study, two theoretical studies for the need of cash level i.e. Trade off theory and the Pecking order theory, are discussed. Cash holding needs good cash planning. Prediction of cash is a process of estimating the probable sources and application of cash over a fixed future period. It is a process that overall financial status of a company is identified and determines probable financial needs with the help of budget.

Regulation of cash flow is known as cash control. After projecting the cash flows, the finance manager is sure that there should not be any differences in the projected and actual figures of cash. Proper management of cash flows, the cost of financing should be minimized and operating activities of the organization are improved. The main techniques of controlling cash flows are Accelerating Cash Inflows and Control over Cash Payments. Accelerating cash flow can be executed with the help of three methods viz. Centralization of Cash functions, internal control over cash receipts and Streamlining of banking arrangements. Concentration banking and Lock-box system helps the streamlining of banking arrangements (Dittmar \& Mahrt-Smith, 2007).

A good cash management system must have an organizational framework, which controls the cash flow. Such framework identifies who is responsible for particular function viz. collecting cash, payment authorization, making payments, bank accounts and funds transfer between accounts, arranging overdraft facilities and loans, investing cash surpluses and foreign currency transaction. A credit availability can solve all these problems. When the `real economy’ falls into recession, businesses face the additional risk of customers running into financial difficulty and becoming unable to pay invoices, which insists the organization to use non-operational sources such as bank loans, can push a company over the edge (Emery, 1987; Myers, 1977; Myers \& Majluf, 1984).

Use of credit is a complex phenomenon. But, common people or even like us have wrong conception or negative idea about implementation as well as application of credit. 'Buy now-pay later' or promise to pay in future for immediate goods are existed in the earlier agricultural societies. Giving credit means we are taking risk. Credit analysis is actually the risk analysis. The credit analyst must consider the nature and type of the business as well as the applicant in his personal judgment. 
It is the age of Credit. Nothing can possible in the world of business, without the liberal extension of credit. It is an indispensable convenience or a necessity in our scheme of living. Use of credit is a complex phenomenon. It is not a recent phenomenon like the disaster of Uttarakhand (India). Use of credit can be found as early as 1300 B.C in the civilization of Babylon, Assyria, Egypt. Today credit system is the destiny of past's way path of credit system.

It is generally observed that information collected from credit applicants are not sufficient for credit decision making. For that reason, organizations are generally taken decisions from the view point of past experience or impression of the customer. Proper evaluation of risk regarding credit granting decision becomes very important before the commencement of sales because once the credit is accepted by creditor organization of its credit applicant, servicing and loss mitigation technique can control the future losses only to a limited extent. The pros and cons of the situation can affect the decision.

Therefore, the data required for the credit analysis must be changed or adjusted subject to the requirement. The next step is to application of some analytical procedure to the financial figure for judging creditworthiness of applicant. To develop the financial as well as statistical technique are fairly recent and still in process. The generally used financial tools are ratio analysis, sources and application of fund analysis, trend analysis, common size statement and other analysis determining the financial position of the applicant (Koen \& Oberholster, 1999; Keynes, 2006).

\section{Literature review}

Moss and Stine (1993) carried out a study regarding the liquidity of the firms. They suggested that the useful way of assessing the liquidity of firms was with the cash conversion cycle. It measured the lag between cash payments for purchase of inventories and collection of receivables from customers. According to them current ratio and quick ratio were the useful measures of the liquidity of the firms. They also focused on the static balance sheet values and firm size was a factor in the length of the cash conversion cycle (CCC). Jose et al. (1996) made a study on liquidity management. In this study they argued that for long-time prospects and healthy bottom lines of the business, we needed good liquidity management. They also mentioned that the cash conversion cycle was a dynamic measure of ongoing liquidity management. It combined both the balance sheet and income statement data for measurement. They also argued that there was a significant and negative relation between profitability and CCC. Uyar (2009) undertook a study on cash conversion cycle regarding its firm size and profitability. For this study, he selected seven industries relating to merchandising and manufacturing sectors. All total 166 corporations were selected. He showed that retail/wholesale industry had shorter CCC than manufacturing industries did. He also indicated that there was a significant negative correlation between the length of CCC and the firm size. He also opined that the correlation between the length of CCC and the profitability was also negative. Farris II et al. (2011) made a study on cash to cash metric. The study presented an overview of cash to cash and its calculation, comparisons between product and service industries etc. The study also revealed that cash-to-cash knowledge of managers helped the service industries improve their liquidity position and overall value.

Ortín-Ángel and Prior (2004) made a study on accounting turnover ratios and cash conversion cycle. The main objective of the study was to deduce the amount of days spent completing an operational process from turnover ratios. This study provided additional tools for financial statements analysis in order to get accurate result or working capital management. Opler et al. (1999) undertook a study on corporate cash holdings. In this study they suggested that dividend paying firms or those that could easily sell assets hold lower levels of cash. They argued that firms with multiple product lines and low inventory levels relative to sales had shorter cash conversion cycles and therefore hold less cash. They also argued that through derivatives cash holdings can be reduced by coordinating risk management and cash management activities. 
The presents study is prepared to make an in-depth analysis of the selected companies in Consumer Durable sector in respect of their Cash Conversion Cycle, Cash Holding and Cash flow and Credit Worthiness over the period 2002-2011. More specifically the objectives of our study as a whole are as under,

1. To design an effective Cash Management policy for smooth cash procurement and disbursement without endangering the operating capability and productivity of the firm,

2. To determine the exact working cash balance in conformity with the nature of the firm and how the temporarily unused fund be invested in interest earning assets,

3. To make a comparative analysis of the Liquidity position (Cash Holding) of selected companies from Consumer Durable sector during the period covered in the study, i.e. 2002 to 2011,

4. To find out the Cash Conversion Cycle with help of RCP, ICP and PDP of the Selected Companies through the technique of ratio analysis and other statistical tools,

5. To measure the Credit Score (CS) and try to establish a relationship among Cash Conversion Cycle, Cash Holding and Creditworthiness.

Five popular companies from Consumer Durable sector have been selected for the study. The data of the selected companies for the period 2002 to 2011 used in this study have been taken from the secondary sources i.e. Capitaline Corporate Database of Capital Market Publishers (I) Ltd. Mumbai.

Cash Conversion Cycle (CCC): Cash Conversion Cycle can be framed with the help of Receivable conversion period, Inventory conversion period and payment deferral period. Shorter cash conversion cycle means better liquidity position of the organization. Here, we established the relationship between CCC and debtors more than six months, CCC and CR, CCC and inventory turnover ratio, CCC and debtors turnover ratio and CCC and creditors turnover ratio. Efficiency of the inventory management has been measured by inventory turnover ratio (ITR) which is the ratio between cost of goods sold and average stock. Higher ITR means lower CCC. So, ITR is negatively associated with CCC. Debtors' turnover ratio (DTR) is the ratio of credit sales to average receivables. Higher DTR indicates lower CCC. Hence, DTR is also negatively related with CCC. Organization's ability to avail credit facility from suppliers has been measured by creditors' turnover ratio (CTR) which is the ratio of credit purchase to average payables. Low CTR means shorter CCC. Therefore, CCC is positively related with the CTR.

Profitability, size of the organization and cumulative profitability can influence the cash conversion cycle of the organization. In this study profitability has been measured by return on net worth (RONW), size of the organization has been represented through the amount equal to the log value of total assets. Shareholders fund has been selected in this study as cumulative profitability which consists of equity share capital and reserve surpluses. The log value of shareholders' fund represents the cumulative profitability (Solomon \& Pringle, 1981; Van Horne, 1968; Walker, 1991).

Average Cash Holding: Opening balance and closing balance of cash are used to determine the average cash balance of each year and again such cash balances are used to get the average cash holding. Large cash holding is preferable for better liquidity of the organization.

The relationship between Average Cash Holding and DFL, Average Cash Holding and Investment and Average Cash Holding and Profitability (RONW) are examined in this study. Degree of financial leverage (DFL) is computed with the help of the following formula,

$$
\text { DFL = Operating Profit (EBIT) / (Operating Profit - Interest) }
$$

The use of fixed charges carrying funds in the capital structure give birth of financial leverage. Inclusion of debt capital in the capital structure increases the financial leverage. Financial risk of the organization 
can be measured by degree of financial leverage (DFL). DFL affect the cash holding of the organization. More external borrowing means more cash holding. Therefore, Cash Holding is positively related with DFL.

But large organization means too many expenses and for that purpose need large cash holding. Therefore, Cash Holding is positively associated with the size of the organization. Investment of the organization has been represented through the figure equal to the log value of total amount of Investment. Organization which have numerous investment opportunities but uncertain internal cash flow hold more cash otherwise borrowing external funds for profitable investment opportunity is costly. Hence, Cash Holding is positively associated with Investment. In this study profitability has been measured by the return on net worth (RONW). General principle is that higher the liquidity lowers the profitability. Holding more cash increases the short-term debt paying capacity of the organization, but decreases the profitability by not using the excess or unused fund in some other profitable projects.

Creditworthiness: We used Bathory's - 'risk description model' after minor changes to develop credit evaluation model from the financial statement of the companies selected in this study. In actual model the main influencing factors are accumulated profitability and inventory but for our purpose we use the cash flow instead of Inventory. Eight different ratios are calculated from the financial statement as stated above. In determination of ratios, emphasis has been given on the firms' liquidity, profitability and capital adequacy. For the purpose of our study five companies each from five different sectors have been selected, as stated earlier, with the help of purposive sampling procedure. The model is prepared on the basis of ten years data; it will be more predictive and reveals the appropriate creditworthiness of the companies. For analyzing the date statistical tools like arithmetic mean, percentage etc. and statistical technique like Pearson's simple correlation analysis and statistical test like ' $\mathrm{t}$ ' test have been applied at appropriate places.

\section{Risk Description Model:}

1. Net Profit / Capital Employed = Profitability (Annual)

2. Net Tangible assets (Shareholders Fund) / Total Liabilities (Long term + Short term debt) $=$ Profitability (Cumulative)

3. Net Profit / Current Liabilities = Liquidity

4. Normalized working capital / Credit Exposure = Capital Adequacy

5. Equity / Current Liability + Credit exposure = Capital Adequacy

6. $\quad$ Net Assets $/$ Credit exposure $=$ Comfort Margin

7. Total assets $/$ Total liability + Credit exposure $=$ Debt Capacity

8. Net Profit + Depreciation/ Current Debt $=$ Priority debt service ability.

In the first ratio we find out the ratio showing profitability. It is also known as return on capital employed. Here, net profit means profit after tax but before interest. In this ratio net profit is placed on capital employed for the measurement of profitability of the current year. Second ratio is calculated by placing the net tangible assets on total liabilities. Here, net tangible assets signify the shareholders fund and total liabilities is equal to the long-term debt plus total short-term debt.

Here, we use the net profit to current liabilities ratio as the indicator of liquidity. Net profit of an organization generally includes some items additional to current assets such as surplus after accounting for depreciation and extra ordinary items. Current liabilities here we consider the items which are payable within a particular accounting period. Another liquidity ratio i.e. fourth ratio is computed by placing Normalized Working Capital to over credit exposure. And normalized working capital is calculated by deducting the stock from net current assets (i.e. Net Working Capital).

Fifth ratio measure the capital adequacy of the companies selected under study. Capital adequacy of the organization measure the long-term capital or permanent capital. Generally, long-term capital is not used to meet the short-term obligation of the organization. In the sixth ratio net assets is placed over 
credit exposure. In the model it is termed as comfort margin. In the fourth ratio, normalized working capital is placed over the credit exposure. Most of the cases, it produces comparatively high values and probably negative. As we know that stock is a very substantial part of current assets and we deduct stock from net current assets, there is a very high probability of a negative figure.

In the seventh ratio total assets is placed over total liability plus credit exposure. It signifies the debt capacity of the organization. Here total liabilities include both short-term liabilities and long-term liabilities. In the ratio total liability also include the credit exposure. It indicates the safety margin taking into consideration of all known obligations including the credit asked by the customer. Finally, in the eighth ratio the treatment of priority debt items is measure by contrasting current debt with financial flow that will be servicing it. Computing gross cash flow from modified accounting information will be difficult without a detailed profit and loss account showing depreciation. In our model eight ratios are taken into consideration by giving equal weight to them. The resulting formula would be denoted as $C S=L \sum x_{i}$ where CS represents credit scores and $x_{i}$ represents variables, i.e. $i=1, \ldots, 8$, and finally $L$ represents constant multiplier, which is $100 / 8=0.125$.

\section{Risk Description Model}

Here, $\quad$ NWC $=$ Normalized Working Capital, NTA $=$ Net Tangible Assets, $E=$ Equity Shareholders fund, CL = Current Liabilities, $\quad$ TL $=$ Total Liabilities, CR. EXPOSU $=$ Credit Exposure $(0.25 \%$ of $\mathrm{CA}), \mathrm{CD}=$ Current Debt, $\mathrm{D}=$ Depreciation, $\mathrm{NP}=$ Net Profit, $\quad \mathrm{NA}=$ Net Assets, $\mathrm{CE}=$ Capital Employed. For analyzing the data statistical tools like arithmetic mean, standard deviation, coefficient of variation etc. and statistical techniques like Pearson's simple correlation analysis and multiple regression analysis and statistical test like ' $t$ ' test have been applied at appropriate places.

\section{Findings of the Study}

From Table 1 it has been depicted that in Consumer Durables sector, the CCC of Hawkins Cooker Ltd. (Hawkins) is highest in the year 2002 (134 days) and smallest in the year 2010 (47.71 days). On an average it is 72.8 days. The company followed a moderate liquidity position during the study period. There is a decreasing trend in CCC is noticed throughout the study period except in the year 2011.

Table 1

Analysis of Cash Conversion Cycle of Selected Companies of Consumer Durable Sectors (in Days)

\begin{tabular}{ccccccccccccc}
\hline HAWKINS & 134.12 & 114.48 & 84.31 & 77.55 & 66.48 & 53.91 & 51.60 & 49.12 & 47.71 & 48.93 & 72.8 \\
\hline HAVELLS & 96.62 & 100.91 & 97.55 & 87.95 & 62.65 & 32.60 & 27.86 & 22.89 & 16.22 & 20.99 & 56.6 \\
KHAITAN & 77.01 & 67.01 & 67.81 & 71.02 & 94.40 & 121.14 & 126.45 & 83.92 & 112.73 & 112.85 & 93.4 \\
VOLTAS & 47.52 & 50.89 & 63.47 & 81.68 & 104.23 & 139.33 & 165.87 & 200.17 & 131.42 & 30.04 & 101.46 \\
SIEMENS & -63.95 & -61.27 & -38.99 & -7.46 & 3.93 & -7.47 & 23.45 & 58.09 & 56.01 & 64.66 & 2.7 \\
\hline
\end{tabular}

Table 1 shows that the CCC of Havells India Ltd. (Havells) is the highest in the year 2003 (100.91 days) and the lowest in the year 2010 (16.22 days). On an average it is 56.6 days. The company improved its liquidity position during the second half of the study period. From Table 1, it is observed that the CCC of Khaitan Electricals Ltd. (Khaitan) fluctuated during the study period. The highest CCC is noticed in the year 2008 (126.45 days) and contrary the lowest CCC is noticed in the year 2003 (67.01 days). On an average it is 93.4 days. During the first half of the study period the company maintained a moderate CCC as compared to the second half of the study period. In case of Voltas Ltd. (Voltas) the situation is quite volatile. From Table 1 it is depicted that the CCC of the company is highest in the year 2009 (200.17 days) and smallest in the year 2002 (47.52 days). On an average it is 101.46 days. It registered an upward trend during the study period except in 2010 and 2011. Table 1 depicts that the CCC of Siemens Ltd. (Siemens) is highest in the year 2011 (64.66 days) and lowest in 2002(-63.95 days). On an average it is 2.7 days. Beginning of the study period the CCC of the company is negative. It is due to high deferral period for payments. But at the end of the study period its liquidity position decreases as CCC increases. 
Hence, the CCC of Siemens is good among other companies of consumer durable sector. The liquidity position of Siemens Ltd. is good as compared to other companies in that group. It emphasizes the efficient liquidity management system of Siemens. Figure-1 also states that Voltas maintained highest CCC whereas Siemens registered the lowest CCC.

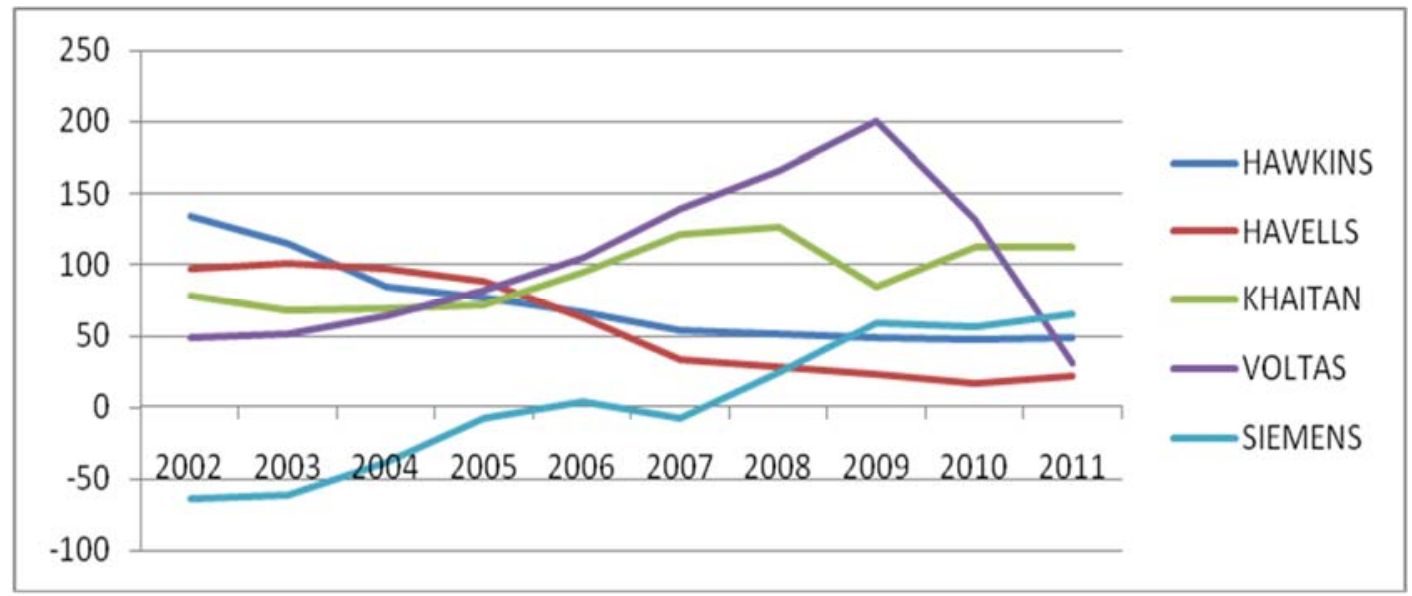

Fig. 1. Cash conversion cycle of consumer durable sector

In Table 2, the values of average Cash Conversion Cycle (CCC) of the companies under study have been ascertained by applying arithmetic mean and consistency of CCC have also been measured by using the coefficient of variation $(\mathrm{CV})$ of their cash conversion cycle. In Consumer Durable sector the average CCC of Siemens is the lowest and followed by Havells, Hawkins, Khaitan and Voltas respectively in that order. Table 2 also reveals that in respect of consistency of designing CCC Khaitan occupied the first position, followed by Hawkins, Voltas, Havells and Siemens respectively. From both average and consistency point of view Hawkins and Khaitan captured the top most position, Havells and Siemens are in second place followed by Voltas.

\section{Table 2}

Ranking on the basis of Average and Consistency of Cash conversion Cycle of the Selected Companies of Consumer Durable Sector

\begin{tabular}{cccccccc}
\hline COMPANIES & AVG. & SD & $\begin{array}{c}\text { RANK } \\
\text { OF }\end{array}$ & $\begin{array}{c}\text { COEFFICIENT } \\
\text { OF }\end{array}$ & $\begin{array}{c}\text { RANK } \\
\text { OF }\end{array}$ & $\begin{array}{c}\text { TOTAL } \\
\text { RANK }\end{array}$ & $\begin{array}{c}\text { OVER } \\
\text { ALL }\end{array}$ \\
\hline HAWKINS & 72.8 & 30.2917 & 3 & 41.594 & 2 & 5 & 1 \\
HAVELLS & 56.6 & 36.0528 & 2 & 63.671 & 4 & 6 & 3 \\
KHAITAN & 93.4 & 23.155 & 4 & 24.782 & 1 & 5 & 1 \\
VOLTAS & 101 & 56.4052 & 5 & 55.592 & 3 & 5 & 5 \\
SIEMENS & 2.7 & 47.9163 & 1 & 1773.4 & 5 & 6 & 3 \\
\hline
\end{tabular}

Source: Compiled and computed from 'Capitaline Corporate Database’ of Capital Market Publishers (I) Ltd., Mumbai.

Coefficient of Correlation is the measurement of degree of association between two variables. A positive value of ' $r$ ' indicated high values of one variable are generally associated with the high values of other variables and low values with low values. In Table 3, an effort has been made to measure the degree of relationship between Cash Conversion Cycle (CCC) and each of the factors related with CCC such as inventory turnover ratio (ITR), current ratio (CR), debtors turnover ratio (DTR), debtors more than six months (Debt>6Months) and creditors turnover ratio(CTR). To test the significance of such coefficient, 't' test has been applied. 
According to Richards-Laughlin, CCC is the sum of receivables conversion period (RCP) plus the inventory conversion period (ICP) minus the payment deferral period (PDP) i.e. CCC = RCP + ICP PDP. Table 3 depicts that the correlation coefficients between CCC and ITR in Hawkins, Khaitan and Voltas are $0.993,0.752$ and 0.945 respectively such are statistically significant at $5 \%$ level. It shows that there was a positive associations between CCC and ITR in these three companies were highly significant. Due to higher ITR, the CCC is the minimum in these three companies. On the other hand, the correlation coefficient between CCC and ITR in Havells and Siemens are negative and statistically insignificant both at $5 \%$ and $1 \%$ level of significance.

\section{Table 3}

Karl Pearson's simple correlation analysis between CCC and ITR, CR, DTR, Debt > 6 months and CTR of the selected companies of consumer durable sector

\begin{tabular}{|c|c|c|c|c|c|c|c|c|c|c|}
\hline \multirow[t]{2}{*}{ COMPANIES } & \multicolumn{2}{|c|}{ CCC \& ITR } & \multicolumn{2}{|c|}{ CCC \& CR } & \multicolumn{2}{|c|}{ CCC \& DTR } & \multicolumn{2}{|c|}{$\begin{array}{c}\text { CCC \& DEBT > } 6 \\
\text { MONTHS }\end{array}$} & \multicolumn{2}{|c|}{ CCC \& CTR } \\
\hline & $(\mathrm{r})$ & 't' Value & (r) & 't' Value & (r) & 't' Value & $(\mathrm{r})$ & 't' Value & $(\mathrm{r})$ & 't' Value \\
\hline HAWKINS & $0.993 * *$ & 23.78 & $0.722 *$ & 2.952 & $0.933^{* *}$ & 7.333 & 0.533 & 1.782 & $0.710^{*}$ & 2.8517 \\
\hline HAVELLS & -0.328 & -0.98 & -0.219 & -0.63 & $0.846^{* *}$ & 4.488 & $-0.858 * *$ & -4.72 & $-0.669 *$ & -2.546 \\
\hline KHAITAN & $0.752 *$ & 3.227 & -0.416 & -1.29 & 0.553 & 1.877 & -0.386 & -1.18 & 0.449 & 1.4213 \\
\hline VOLTAS & $0.945^{* *}$ & 8.172 & 0.608 & 2.166 & -0.359 & -1.09 & 0.087 & 0.247 & $0.670^{*}$ & 2.5527 \\
\hline SIEMENS & -0.179 & -0.51 & 0.017 & 0.048 & -0.050 & -0.14 & 0.102 & 0.29 & 0.276 & 0.8122 \\
\hline
\end{tabular}

From Table 3 it is found that the correlation coefficient between CCC and CR in Hawkins, Voltas and Siemens are $0.722,0.608$ and 0.017 respectively. Out of which only in case of Hawkins, the correlation coefficient is significant at 5\% level. It implies positive association between CCC and CR in these three companies. On the other hand, negative correlation between CCC and CR is noticed in case of Khaitan (-0.416) and Havells (-0.219).

Table 3 exhibits that the correlation coefficients between CCC and DTR in Hawkins, Havells and Khaitan are $0.933,0.846$ and 0.533 , respectively. Out of which the correlation coefficient between CCC and DTR of Hawkins and Havells are statistically significant both at 5\% and 1\% level of significance. On the other hand Voltas and Siemens registered a negative correlation between CCC and DTR which are (-) 0.359 and (-) 0.050 respectively. It implies negative association between CCC and DTR.

Table 3 exhibits that the correlation coefficients between CCC and Debtors more than six months in Havells and Khaitan are (-)0.858 and (-)0.386 respectively. Out of which the same in case of Havells is statistically significant at $5 \%$ level of significance. It implies negative association between CCC and debtors more than six months in case of Havells and Khaitan. On the other hand the correlation coefficient between CCC and debtors more than six months in Hawkins, Voltas and Siemens are 0.533, 0.087 and 0.102 respectively.

It has been found from Table 3 that the correlation coefficient between CCC and CTR in Havells is (-) 0.669 which is statistically significant at $5 \%$ level. It indicates the negative association between CCC and CTR which help to reduce the CCC. The correlation coefficient between CCC and CTR in Hawkins, Khaitan, Voltas and Siemens are 0.710, 0.449, 0.670, and 0.276 respectively. Out of which the same in case of Hawkins, Havells and Voltas is statistically significant at 5\% level. It implies positive association between CCC and CTR which is theoretically accepted.

From the correlation analysis between CCC and ITR except Havells and Siemens fulfill the theoretical proposition. The correlation between CCC and CR we can conclude that except Havells and Khaitan, other companies supported the theoretical proposition. On the other hand, the correlation between CCC and DTR, only Voltas and Siemens authenticated the theoretical proposition. The correlation between Debtors more than 6 months and CCC it is clear that only Havells and Khaitan supported the theoretical 
proposition. Lastly, the correlation between CCC and CTR, it is observed that except Havells all other companies followed the theoretical proposition. So, out of five companies of Consumer Durable sector only in case of Siemens all the theoretical proposition has been matched.

In Table 4 an attempt has been made to assess the influence on profitability, size of the organization and cumulative profitability on Cash Conversion Cycle. In this study, return on net-worth (RONW) has been taken as the measure of owners' profitability, log value of total assets has been taken as the measure of size of the organization and shareholder's fund has been taken as the measure of cumulative profitability. The linear regression equation has been fitted in this study is CCC $=\mathrm{b}_{0}+\mathrm{b}_{1} \mathrm{RONW}+$ $\mathrm{b}_{2}$ Size of Org. + $\mathrm{b}_{3}$ Shareholders' fund, where $\mathrm{b}_{0}$ is the value of intercept term (constant ) and $\mathrm{b}_{1}, \mathrm{~b}_{2}$ and $b_{3}$ are the slopes of the line i.e. the regression coefficient of CCC on RONW, size of org. and Shareholders' fund. This regression equation has been tested by ' $t$ ' test.

Table 4 shows that for once unit increase in RONW the CCC of Hawkins Ltd. stepped up by only 0.013 units which is also statistically insignificant at $5 \%$ level. Table 4 also depicts that for one unit increase in size of the organization the CCC of Hawkins Ltd. go down by 8.399 units which is significant at 1\% level. On the other hand, the table reveals that for one unit increase in cumulative profitability the CCC of go up by 7.104 units which is statistically significant at 5\% level of significance. It implies that the influence of RONW and cumulative profitability on CCC is positive and last one is statistically significant at 5\% level while the influence of size of the organization on CCC of the company is negative. The coefficient of determination $\left(\mathrm{R}^{2}\right)$ makes it clear that $95.7 \%$ of the variation of the company's CCC is accounted for by the variation in RONW, Size of Org and Shareholders' fund.

Table 4 depicts that for one unit increase in RONW the CCC of Havells is decreased by 0.133 units which is statistically insignificant at $5 \%$ level while table- 4 shows that for one unit increase in the size of the organization the CCC of Havells stepped down by 4.993 units. Table 4 also depicts that for one unit increase in share holders' fund the CCC of the organization rapidly increase by 12.795 units which is also statistically insignificant. It indicates that the influence of cumulative profitability on CCC of the Havells is positive whereas RONW and size of the organization is negatively influenced the CCC of the company. The coefficient of determination $\left(\mathrm{R}^{2}\right)$ makes it clear that $91.4 \%$ of the variation of the company's CCC is accounted for by the variation in RONW, Size of Org and Shareholders' fund.

It has been found from Table 4 that for one unit increase in profitability the CCC of the Khaitan is increased by only 0.143 unit which is statistically significant at $5 \%$ level of significance. For one unit increase in size of the organization the CCC of Khaitan is go up by 11.292 units which is statistically insignificant. From table- 4 it is found that for one unit increase in cumulative profitability the CCC of the company is highly decreased by 42.217 units which is statistically significant $10 \%$ level. It implies that the profitability and size of the organization is positively influenced the CCC of the Khaitan while cumulative profitability is negatively influenced the CCC of the company. The coefficient of determination $\left(\mathrm{R}^{2}\right)$ makes it clear that $72.0 \%$ of the variation of the company's CCC is accounted for by the variation in RONW, Size of Org and Shareholders' fund.

Table 4 depicts that for one unit increase in RONW the CCC of Voltas Ltd decreased by only 0.216 units which is not statistically significant. Table-4 also depicts that for one unit increase in size of the organization the CCC of Voltas Ltd. stepped up by 9.955 units which is statistically not significant. On the other hand, Table 4 shows that for one unit increase in cumulative profitability the CCC of Voltas Ltd. is decreased by only 2.694 units which is statistically not significant. It indicates that size of the organization is positively influenced the CCC of the Voltas whereas both Profitability and Cumulative Profitability negatively influenced the CCC of Voltas. The coefficient of determination $\left(\mathrm{R}^{2}\right)$ makes it clear that $55.1 \%$ of the variation of the company's CCC is accounted for by the variation in RONW, Size of Org. and Shareholders' fund. 
Table 4 reveals that for one unit increase in RONW the CCC of Siemens stepped up by 2.457 units which is statistically insignificant. Table-4 also portrays that for one unit increase in size of the organization the CCC of Siemens is highly goes down by 76.328 units which is also statistically insignificant. From table-4 it is found that for one unit increase in cumulative profitability the CCC of Siemens is go up by only 0.027 unit which is not significant at $5 \%$ level. It implies that the profitability and cumulative profitability is positively influenced the CCC of Siemens while size of the organization is negatively influenced the CCC of Siemens. The coefficient of determination $\left(\mathrm{R}^{2}\right)$ makes it clear that only $8.1 \%$ of the variation of the company's CCC is accounted for by the variation in RONW, Size of Org and Shareholders' fund.

Therefore, from Table 4 it is found that in case of Khaitan cumulative profitability is negatively influenced the CCC which is very high. On the other hand, in case of Siemens, the size of the organization is negatively influenced the CCC which is also very high.

From the regression analysis it is clear that only in Havells and Voltas, RONW negatively influenced the CCC. On the other hand, in Hawkins, Havells and Siemens the effect of Size of the organization on CCC is negative. The effect of cumulative profitability on CCC is negative in case of Khaitan and Voltas. So with this no such general conclusion can be drawn that this factor has positive or negative impact on CCC.

\section{Table 4}

Analysis of Multiple Regression of CCC on RONW, Size of Org. and shareholders' Fund of the Selected Companies of Consumer Durable Sector

Regression Equation is CCC $=\mathrm{a}_{0}+\mathrm{a}_{1}$ RONW $+\mathrm{a}_{2}$ Size of Org. $+\mathrm{a}_{3}$ Shareholders' Fund

\begin{tabular}{|c|c|c|c|c|c|}
\hline \multirow[t]{2}{*}{ COMPANIES } & \multicolumn{3}{|c|}{ PARTIAL REGRESSION COEFFICIENT } & \multirow[b]{2}{*}{ CONSTANT } & \multirow[t]{2}{*}{$\mathrm{R}^{2} \mathrm{ED}$} \\
\hline & RONW & $\begin{array}{c}\text { SIZE OF THE } \\
\text { ORGANIZATION }\end{array}$ & $\begin{array}{l}\text { SHAREHOLDERS' } \\
\text { FUND }\end{array}$ & & \\
\hline HAWKINS & $\begin{array}{c}0.013 \\
(1.551)\end{array}$ & $\begin{array}{c}-8.399 \\
(-3.434)^{* * *}\end{array}$ & $\begin{array}{c}7.104 \\
(2.915)^{* *}\end{array}$ & $\begin{array}{c}9.387 \\
(4.779)\end{array}$ & 0.957 \\
\hline HAVELLS & $\begin{array}{c}-0.133 \\
(-1.392)\end{array}$ & $\begin{array}{c}-4.993 \\
(-0.353)\end{array}$ & $\begin{array}{l}12.795 \\
(1.398)\end{array}$ & $\begin{array}{c}-2.813 \\
(-0.159)\end{array}$ & 0.914 \\
\hline KHAITAN & $\begin{array}{c}0.143 \\
(2.579)^{* *}\end{array}$ & $\begin{array}{l}11.292 \\
(0.913)\end{array}$ & $\begin{array}{l}-42.217 \\
(-2.252)^{*}\end{array}$ & $\begin{array}{l}59.282 \\
(2.035)\end{array}$ & 0.720 \\
\hline VOLTAS & $\begin{array}{c}-0.216 \\
(-1.638)\end{array}$ & $\begin{array}{l}9.955 \\
(0.184)\end{array}$ & $\begin{array}{c}-2.694 \\
(-0.059)\end{array}$ & $\begin{array}{c}-8.206 \\
(-0.263)\end{array}$ & 0.551 \\
\hline SIEMENS & $\begin{array}{c}2.457 \\
(0.615)\end{array}$ & $\begin{array}{l}-76.328 \\
(-0.328)\end{array}$ & $\begin{array}{c}0.027 \\
(0.368)\end{array}$ & $\begin{array}{l}116.962 \\
(0.230)\end{array}$ & 0.081 \\
\hline
\end{tabular}

Source: Compiled and computed from ‘Capitaline Corporate Database’ of Capital Market Publishers (I) Ltd., Mumbai.

\section{Cash Holding}

It is found from Table 5 that the Average Cash Holding (ACH) of Hawkins Cooker Ltd. is highest in the year 2011 (Rs.43.73 Crore) and lowest in the year 2006 (Rs.1.755 Crore). On an average it is Rs. 9.63 Crore. The ACH of the company is fluctuated during the first half of the study period but a steady growth in ACH is noticed during the second half of the study period. In the year 2011 the cash holding as percentage of total assets is highest i.e. 65.91\%. The company maintained very low level of cash during the study period except last two years. It has been observed from table-5 that the ACH of Havells India Ltd. (Havells) is highest in the year 2010 (Rs.111.56 Crore) and in the year 2005 (Rs. 0.23Crore). On an average it is Rs. 34.1 Crore. The ACH of the company is very low during the first half. But during the second half the company increased its level of cash holding. Cash holding as percentage of total assets is highest in the year 2009(10.93\%). It also indicates that the company improved its liquidity position in the second half as compared to the first half of the study period.

From Table 5 it is observed that the ACH of Khaitan Electricals Ltd. (Khaitan) is highest in the year 2002 (Rs.2.1 Crore) and lowest in the year 2011 (Rs.0.64 Crore). On an average it is 1.44. The company 
followed a mixed trend in ACH during the period under study. Throughout the study period the company maintained very low level of cash. But, from the point of view of cash holding as percentage of total assets year 2002 (2.63\%) is the best and decreases during the study period. It may be due to raising external funds or investment in some profitable projects.

Table 5 shows that the ACH of Voltas Ltd. (Voltas) is highest in the year 2011 (Rs.416.94 Crore) and lowest in the year 2002 (Rs.56.88 Crore). On an average it is 196 Crore. The company maintained a steady increasing trend in ACH during the study period except the year 2007. In the year 2006, cash holding as percentage of total assets is highest which $40.56 \%$. The company maintained moderate level of cash during the study period. From table-5 it is revealed that the ACH of Siemens Ltd. (Siemens) is highest in the year 2011 (Rs.1649.17 Crore) and lowest in the year 2003 (Rs.145.6 Crore). On an average it is Rs. 627 Crore. A mixed trend in ACH is followed by the company. Throughout the study period, the company increases the ACH. It indicates that the liquidity position of the company is better in the second half as compared to the first half of the study period. Cash holding as percentage of total assets is highest in the year 2007 (65.42\%).

Table 5

Analysis of Average Cash Holding (Avg. cash holding as percentage of total assets) of Selected Companies of Consumer Durable sector Rs. in crore (also in \% of total assets)

\begin{tabular}{cccccccccccc}
\hline & \multicolumn{1}{c}{ COMPANIES } & \multicolumn{1}{c}{ Years } & \multicolumn{1}{c}{ A } & \multicolumn{1}{c}{ AVG. } \\
& 2002 & 2003 & 2004 & 2005 & 2006 & 2007 & 2008 & 2009 & 2010 & 2011 \\
\hline \multirow{2}{*}{ HAWKINS } & 2.69 & 2.16 & 1.81 & 1.91 & 1.76 & 2.36 & 3.30 & 9.07 & 27.54 & 43.73 & 9.63 \\
& $(4.8)$ & $(5.95)$ & $(4.99)$ & $(5.69)$ & $(6.14)$ & $(8.56)$ & $(11.76)$ & $(25.53)$ & $(53.81)$ & $(65.91)$ & $(19.3)$ \\
& 0.56 & 0.50 & 0.24 & 0.23 & 0.41 & 13.54 & 45.42 & 109.83 & 111.56 & 58.26 & 34.1 \\
HAVELLS & $(0.54)$ & $(0.37)$ & $(0.24)$ & $(0.09)$ & $(0.14)$ & $(4.25)$ & $(45.415)$ & $(10.93)$ & $(8.92)$ & $(3.95)$ & $(3.58)$ \\
KHAITAN & 2.1 & 1.80 & 1.85 & 1.77 & 1.71 & 1.47 & 1.20 & 1.015 & 0.86 & 0.64 & 1.44 \\
& $(2.63)$ & $(2.22)$ & $(2.29)$ & $(2.24)$ & $(1.99)$ & $(1.79)$ & $(1.38)$ & $(1.07)$ & $(0.92)$ & $(0.67)$ & $(1.73)$ \\
VOLTAS & 56.88 & 80.42 & 90.86 & 118.6 & 127.15 & 124.44 & 207.73 & 337.73 & 401.83 & 416.94 & 196 \\
& $(19.95)$ & $(31.92)$ & $(33.37)$ & $(39.55)$ & $(40.56)$ & $(26.88)$ & $(35.45)$ & $(39.39)$ & $(39.62)$ & $(30.53)$ & $(33.7)$ \\
SIEMENS & 156.51 & 145.6 & 230.58 & 344.7 & 458.25 & 712.48 & 701.53 & 688.36 & 1179 & 1649.17 & 627 \\
& $(48.22)$ & $(37.71)$ & $(46.66)$ & $(56.60)$ & $(58.5)$ & $(65.42)$ & $(44.05)$ & $(33.25)$ & $(40.42)$ & $(47.42)$ & $(47.8)$ \\
\hline
\end{tabular}

Source: Compiled and computed from ‘Capitaline Corporate Database’ of Capital Market Publishers (I) Ltd., Mumbai.

Under Consumer Durables sector Siemens maintained higher level of cash during the study period as compare to other companies. It helps the company to improve its liquidity position. From Fig. 2 same conclusion can be drawn and it is clear that the average level of Cash Holding increases throughout the study period.

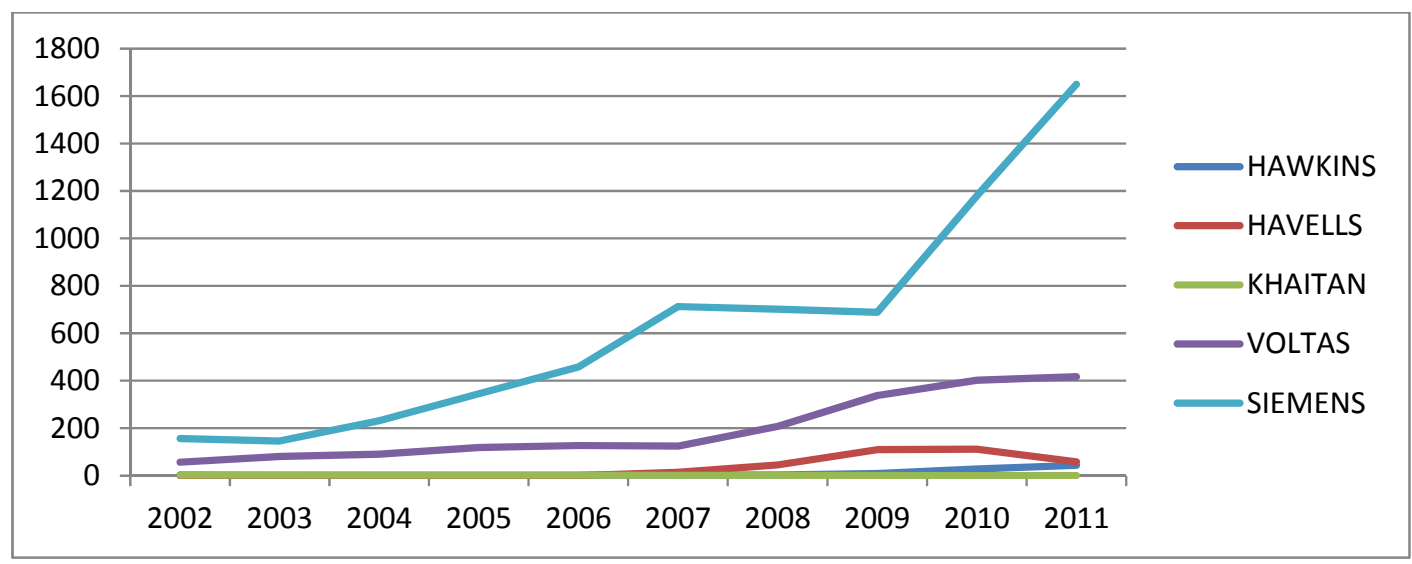

Fig. 2. Avg. Cash Holding

In Table 6 the values of average cash holding as percentage of total assets of the companies under study have been ascertained by applying arithmetic mean and consistency of ACH have also been measured 
by using the coefficient of Variation (CV) of their average cash holding. First of all industry wise ranks have been assigned to the selected companies both in respect of average and consistency.

It has been found from Table 6 that the Average Cash Holding as \% of Total Assets of Siemens is the highest and followed by Voltas, Hawkins, Havells, and Khaitan respectively in that order. Table 6 also reveals that in respect of consistency of formulating $\mathrm{ACH}$, Khaitan holds the first position followed by Voltas, Siemens, Havells and Hawkins respectively. Considering both average and consistency aspects together Voltas and Siemens are jointly the best and it followed by Khaitan, Hawkins and Havells in that order.

Coefficient of correlation is the measurement of degree of association between two variables. A positive value of ' $r$ ' indicated high values of one variable are generally associated with the high values of other variables and low values with low values. In table-7 an effort has been made to measure the degree of relationship between ACH and each of the factors related with cash holding such as degree of financial risk (DFL), size of the organization, Investment of the organization and lastly profitability (RONW). To test the significance of such coefficient ' $t$ ' test has been applied.

Table 7 reveals that the correlation coefficient between ACH and DFL in Hawkins, Havells, Khaitan, Voltas and Siemens are 0.12, (-) 0.497, 0.101, 0.760 and (-) 0.603 respectively. Out of which the correlation coefficient between ACH \& DFL in Voltas is statistically significant at 5\% level. It indicates the strength of positive association between ACH and DFL in Hawkins, Khaitan, and Voltas. On the other hand, the correlation coefficient between ACH and DFL in Havells and Siemens are negative.

It is found from Table 7 that the correlation coefficient between ACH and Size of the organization in Hawkins, Havells, Khaitan, Voltas and Siemens are 0.706, 0.894, (-) 0.916, 0.951 and 0.969 respectively. Out of which the correlation coefficient between ACH and size of the organization in Hawkins, Havells, Voltas and Siemens are positive and statistically significant either in $5 \%$ or $1 \%$ or both $5 \%$ and $1 \%$ level of significance. It implies the strength of positive association between ACH and Size of the Organization in these companies. On the other hand, the correlation coefficient between $\mathrm{ACH}$ and Size of the organization in Khaitan is negative and statistically significant at $1 \%$ level. It indicates that in Khaitan Ltd the relationship between ACH and Size of the organization is negative.

Table 7 shows that the correlation coefficients between ACH and Investment in Hawkins, Havells, Khaitan, Voltas and Siemens are (-)0.271, 0.856, (-) 0.819, 0.940 and 0.908 respectively. In these correlation coefficients, the same in case of Havells, Voltas, and Siemens are positive and are statistically significant both at $5 \%$ and $1 \%$ level of significance. It indicates that in Havells, Voltas and Siemens, ACH is positively related with Investment. Contrary, the correlation coefficients between $\mathrm{ACH}$ and Investment in Hawkins and Khaitan are negative. Out of which the coefficient in Khaitan is statistically significant both at 5\% and 1\% level of significance. It implies that in Hawkins and Khaitan the relationship between ACH and Investment is negative.

It is found from Table 7 that the correlation coefficient between ACH and RONW in Hawkins, Havells, Khaitan, Voltas and Siemens are 0.712, (-) 0.572, 0.835, 0.657 and 0.425 respectively. Out of which the correlation coefficients between ACH and RONW in Hawkins, Khaitan, Voltas and Siemens are positive and the same in Hawkins, Khaitan and Voltas are significant either at $5 \%$ or at $1 \%$ level of significance. It implies that ACH and RONW is positively associated in Hawkins, Khaitan, Voltas and Siemens. But the correlation coefficient between ACH and RONW in Havells is negative. It implies the negative association between ACH and RONW.

From the correlation analysis it is observed that the relationship between DFL and ACH in Hawkins, Khaitan and Voltas is positive which supported the theoretical proposition. Theoretically, size of the organization is positively associated with ACH. Except Khaitan in other companies the relationship is positive which also supported the theoretical proposition. Theoretically, RONW is negatively associated with ACH. Only Havells, such relationship is positive. 
Table 7

Karl Pearson’s Simple Correlation Analysis between AVG Cash Holding and DFL, Size of Org., Investment and RONW of the Selected Companies of Consumer Durable Sector

\begin{tabular}{|c|c|c|c|c|c|c|c|c|}
\hline \multirow[t]{2}{*}{ COMPANIES } & \multicolumn{2}{|c|}{$\begin{array}{c}\text { AVG CASH HOLDING \& } \\
\text { DFL }\end{array}$} & \multicolumn{2}{|c|}{$\begin{array}{c}\text { AVG CASH HOLDING \& } \\
\text { SIZE OF ORG. }\end{array}$} & \multicolumn{2}{|c|}{$\begin{array}{c}\text { AVG CASH } \\
\text { HOLDING } \\
\& \\
\text { INVESTMENT }\end{array}$} & \multicolumn{2}{|c|}{$\begin{array}{c}\text { AVG CASH } \\
\text { HOLDING \& } \\
\text { RONW }\end{array}$} \\
\hline & (r) & 't' Value & (r) & 't' Value & (r) & 't' Value & (r) & 't' Value \\
\hline HAWKINS & 0.12 & 0.34 & $0.706^{*}$ & 2.8196 & -0.271 & -0.796 & $0.712^{*}$ & 2.868 \\
\hline HAVELLS & -0.497 & -1.6 & $0.894 * *$ & 5.6434 & $0.856 * *$ & 4.683 & -0.572 & -1.97 \\
\hline KHAITAN & 0.101 & 0.29 & $-0.916 * *$ & -6.458 & $-0.819 * *$ & -4.037 & $0.835^{* *}$ & 4.292 \\
\hline VOLTAS & $0.760 *$ & 3.31 & $0.951 * *$ & 8.6996 & $0.940 * *$ & 7.793 & $0.657 *$ & 2.465 \\
\hline SIEMENS & -0.603 & -2.1 & $0.969 * *$ & 11.093 & $0.908 * *$ & 6.13 & 0.425 & 1.328 \\
\hline
\end{tabular}

Source: Compiled and computed from ‘Capitaline Corporate Database’ of Capital Market Publishers (I) Ltd., Mumbai.

In Table 8 an attempt has been made to assess the influence of DFL, Size of the organization and Investment on Average Cash Holding. In this study DFL has been taken as the measure of financial risk, log value of total assets has been taken as the measure of size of the organization and log value of total investment has been taken as the measure of Investment. The linear regression equation has been fitted in this study ACH $=b_{0}+b_{1}$ DFL $+b_{2}$ Size of the org. $+b_{3}$ Investment, $b_{0}$ is the value of intercept term (constant) and $b_{1}, b_{2}$ and $b_{3}$ are the slopes of the line, i.e. the regression coefficient of ACH on $\mathrm{DFL}$, Size of the organization and Investment. This regression equation has been tested by 't' test.

Table 8 depicts that for one unit increase in DFL the ACH of Hawkins stepped down by only 0.045 units which is statistically insignificant. Table 8 shows that for one unit increase in Size of the organization, the ACH increased by 3.196 units which is statistically significant at $1 \%$ level. The table also reveals that for one unit increase in Investment the ACH of Hawkins decreased by 0.724 units which is insignificant. It indicates that only size of the organisaiton positively influence the ACH of the company whereas the influence of DFL and Investment on ACH is negative. The coefficient of determination $\left(\mathrm{R}^{2}\right)$ makes it clear that $74.3 \%$ of the variation of the company's ACH is accounted for by the variation in DFL, Size of Org and Investment.

It has been found from Table 8 that for one unit increases in DFL, the ACH of Havells decreased by only 0.028 units which is insignificant. For one unit increase in Size of the organization, the ACH increased by 1.733 unit which is statistically significant at $10 \%$ level. The table also portrays that for one unit increase in Investment the ACH of Havells stepped up by 0.374 units which is insignificant. It signifies that the influence of size of the organization and Investment on $\mathrm{ACH}$ is positive whereas the influence of DFL on ACH is negative. The coefficient of determination $\left(\mathrm{R}^{2}\right)$ makes it clear that $84.6 \%$ of the variation of the company's ACH is accounted for by the variation in DFL, Size of Org and Investment.

It is found from table-8 that for one unit increase in DFL the ACH of Khaitan stepped up by only 0.011 units which is statistically significant at $10 \%$ level. For one unit increase in size of the organization, the $\mathrm{ACH}$ of Khaitan goes down by 4.245 units which is statistically in significant. Table 8 also portrays that for one unit increase in Investment the ACH of Khaitan go down by 0.101 unit which insignificant. It indicates that the size of the organization and Investment negatively influenced the ACH of Khaitan, while DFL positively influenced the ACH of the company. The coefficient of determination $\left(\mathrm{R}^{2}\right)$ makes it clear that $90.8 \%$ of the variation of the company's ACH is accounted for by the variation in DFL, Size of Org. and Investment.

Table 8 exhibits that for one unit increase in DFL the ACH of Voltas decreased by 1.017 units which is statistically significant at $5 \%$ level. For one unit increase in size of the organization the ACH of Voltas stepped up by 1.211 units and which is statistically significant at $1 \%$ level. The table shows that for one unit increase in Investment, the ACH of Voltas go down by 0.257 units which is also insignificant. It implies that only the size of the organization influenced the ACH positively whereas DFL and Investment are negatively influenced the ACH of Voltas. The coefficient of determination 
$\left(\mathrm{R}^{2}\right)$ makes it clear that only $96.9 \%$ of the variation of the company's ACH is accounted for by the variation in DFL, Size of the Org. and Investment.

It is found from Table 8 that for one unit increases in DFL, the ACH of Siemens decreased by 1.018 units, which is insignificant. Table-8 also exhibits that for one unit increase in size of the organization the ACH of Siemens increased by 0.721 units which is statistically significant at $1 \%$ level. Table- 8 reveals that for one unit increase in Investment the ACH of Siemens increased by only 0.184 units which is also not significant. It signifies that size of the organization and Investment influence the company positively whereas the influence of DFL on ACH is negative. The coefficient of determination $\left(\mathrm{R}^{2}\right)$ makes it clear that only $96 \%$ of the variation of the company's ACH is accounted for by the variation in DFL, Size of Org. and Investment.

\section{Table 8}

Analysis of Multiple Regression of Avg. Cash Holding on DFL, Size of Org. and Investment of the Selected Companies of Consumer Durable Sectors.

Regression Equation is Avg. Cash Holding $=\mathrm{a}_{0}+\mathrm{a}_{1}$ DFL $+\mathrm{a}_{2}$ Size of Org. $+\mathrm{a}_{3}$ Investment

\begin{tabular}{|c|c|c|c|c|c|}
\hline \multirow{2}{*}{ COMPANY } & \multicolumn{3}{|c|}{ PARTIAL REGRESSION COEFFICIENT } & \multirow{2}{*}{ CONSTANT } & \multirow{2}{*}{$\mathrm{R}^{2} \mathrm{ED}$} \\
\hline & DFL & SIZE OF THE ORGANISTION & INVESTMENT & & \\
\hline HAWKINS & $-0.045(-0.286)$ & $3.196(3.572)^{* * *}$ & $-0.724(-1.680)$ & $-4.948(-3.418)$ & 0.743 \\
\hline HAVELLS & $-0.028(-0.187)$ & $1.733(1.934)^{*}$ & $0.374(0.783)$ & $-3.986(-1.717)$ & 0.846 \\
\hline KHAITAN & $0.011(2.023)^{*}$ & $-4.245(-3.471)$ & $-0.101(-0.701)$ & 8.393(3.723) & 0.908 \\
\hline VOLTAS & $-1.017(-3.181)^{* *}$ & $1.211(3.781)^{* * *}$ & $-0.257(-1.093)$ & $0.586(1.218)$ & 0.969 \\
\hline SIEMENS & $-1.018(-0.285)$ & $0.721(4.416)^{* * *}$ & $0.184(1.181)$ & $1.120(0.300)$ & 0.960 \\
\hline
\end{tabular}

The most interesting fact is that out of five consumers durable companies the size of the organization in four cases positively influenced the $\mathrm{ACH}$ and out of which three are statistically significant. From the regression analysis it is seen that in most of the cases except Khaitan DFL negatively influenced the ACH during the study period. In most of the cases, except Khaitan, size of the organization positively affect the ACH in the study period. On the other hand, except Havells and Siemens, Investment negatively influenced the ACH of the companies during the study period.

\section{Creditworthiness}

The main purpose of calculating ratios is to judge the firm's liquidity, profitability and capital adequacy. From the 'risk description model', scores are calculated individually for each of the selected companies under study. Tables are prepared consisting of different ratios to calculate scores. The model clearly showed that how the liquidity, profitability and capital adequacy factors influenced the scores of individual companies. In case of all the companies from five different sectors, where all the factors are good, they obtained high score. Contrary, the companies where two factors are good but the impact of one or two bad factor / factors outweighed the influence of good factors. This model is self-explanatory in nature. In this case our objective is to gives an idea to the credit analyst, about extracting best result of using financial statement.

Table 9

Risk Description Model - Ratio Measurement(Hawkins)

\begin{tabular}{ccc}
\hline RATIOS & DESCRIPTION & AVG. SCORES \\
\hline X1 & NP/CE & 0.307 \\
X2 & NTA/TL & 0.6868 \\
X3 & NP/CL & 0.3715 \\
X4 & NWC/CR.EXPOSU & 71.228 \\
X5 & E/CL+CR.EXPOSU & 0.6831 \\
X6 & NA/CR.EXPOSU & 129.05 \\
X7 & TA/TL+CR.EXPOSU & 2.1832 \\
X8 & NP+D/CD & 2.1614 \\
TOTAL AVG SCORES & & 206.67 \\
CREDIT SCORES(CS) & \\
\hline
\end{tabular}


Table 9 shows that the average scores of ratio $\mathrm{x}_{1}, \mathrm{x}_{2}, \mathrm{x}_{3}, \mathrm{x}_{4}, \mathrm{x}_{5}, \mathrm{x}_{6}, \mathrm{x}_{7}$ and $\mathrm{x}_{8}$ in Hawkins Cooker Ltd. (Hawkins) are 0.307, 0.6868, 0.3715, 71.228, 0.6831, 129.05, 2.1832 and 2.1614 respectively. The highest score is revealed by ratio $\mathrm{x}_{6}(129.05)$ and lowest score is registered by ratio $\mathrm{x}_{1}(0.307)$. The total average score is 206.67. The credit score of Hawkins Ltd is 25.833.

Table 10 exhibits that the average score of ratio x1, x2, x3, x4, x5, x6, x7 and x8 in Havells India Ltd. (Havells) are 0.2145,1.5491, 0.5221, 72.758, 1.5365, 360.79, 3.172 and 2.5341 respectively. The highest score represented by ratio x6 (360.79) and lowest score registered by ratio x1 (0.2145). The total average score of Havells is 443.08. The credit score of Havells is 55.385.

Table 10

Risk Description Model -Ratio Measurement(Havells)

\begin{tabular}{ccc}
\hline RATIOS & DESCRIPTION & AVG SCORES \\
\hline X1 & NP/CE & 0.2145 \\
X2 & NTA/TL & 1.5491 \\
X3 & NP/CL & 0.5221 \\
X4 & NWC/CR.EXPOSU & 72.758 \\
X5 & E/CL+CR.EXPOSU & 1.5365 \\
X6 & NA/CR.EXPOSU & 360.79 \\
X7 & TA/TL+CR.EXPOSU & 3.172 \\
X8 & NP+D/CD & 2.5341 \\
TOTAL AVG SCORES & & 443.08 \\
CREDIT SCORES(CS) & & 55.385 \\
\hline
\end{tabular}

Table 11 shows that the average score of ratio $\mathrm{x}_{1}, \mathrm{x}_{2}, \mathrm{x}_{3}, \mathrm{x}_{4}, \mathrm{x}_{5}, \mathrm{x}_{6}, \mathrm{x}_{7}$ and $\mathrm{x}_{8}$ in Khaitan Electricals Ltd. (Khaitan) are 0.0335, 3.1395, 0.1195, 86.385, 3.1699, 735.48, 5.0493 and 0.8221 respectively. The highest score represented by ratio $\mathrm{x} 6$ which is 735.48 and lowest score portrayed by ratio $\mathrm{x} 1$ which is 0.0335. The total average score of Khaitan is 834.2. The credit score of Khaitan is 104.28.

Table 11

Risk Description Model - Ratio Measurement (Khaitan)

\begin{tabular}{ccc}
\hline RATIOS & DESCRIPTION & AVG SCORES \\
\hline X1 & NP/CE & 0.0335 \\
X2 & NTA/TL & 3.1395 \\
X3 & NP/CL & 0.1195 \\
X4 & NWC/CR.EXPOSU & 86.385 \\
X5 & E/CL+CR.EXPOSU & 3.1699 \\
X6 & NA/CR.EXPOSU & 735.48 \\
X7 & TA/TL+CR.EXPOSU & 5.0493 \\
X8 & NP+D/CD & 0.8221 \\
TOTAL AVG SCORES & & 834.2 \\
CREDIT SCORES(CS) & & 104.28 \\
\hline
\end{tabular}

Table 12 reveals that the average score of ratio $\mathrm{x}_{1}, \mathrm{x}_{2}, \mathrm{x}_{3}, \mathrm{x}_{4}, \mathrm{x}_{5}, \mathrm{x}_{6}, \mathrm{x}_{7}$ and $\mathrm{x}_{8}$ in Voltas Ltd. (Voltas) are $0.2678,0.2606,0.0838$, (-) 52.46, 0.2889, 89.719, 1.2401 and 0.4798 respectively. Out of which ratio $\mathrm{X} 6$ (89.719) represented the highest score and ratio $\mathrm{x} 4(-52.46)$ revealed the lowest score. The total average score of Voltas is only 39.883. The Credit score of Voltas Ltd. is 4.9853. The negative score of ratio $\mathrm{x} 4$ reduced the total score.

Table 12

Risk Description Model - Ratio Measurement(Voltas)

\begin{tabular}{ccc}
\hline RATIOS & DESCRIPTION & AVG SCORES \\
\hline X1 & NP/CE & 0.2678 \\
X2 & NTA/TL & 0.2606 \\
X3 & NP/CL & 0.0838 \\
X4 & NWC/CR.EXPOSU & -52.46 \\
X5 & E/CL+CR.EXPOSU & 0.2889 \\
X6 & NA/CR.EXPOSU & 89.719 \\
X7 & TA/TL+CR.EXPOSU & 1.2401 \\
X8 & NP+D/CD & 0.4798 \\
TOTAL AVG SCORES & & 39.883 \\
CREDIT SCORES(CS) & & 4.9853 \\
\hline
\end{tabular}


It is found from Table 13 that the average scores of ratio $\mathrm{x}_{1}, \mathrm{x}_{2}, \mathrm{x}_{3}, \mathrm{x}_{4}, \mathrm{x}_{5}, \mathrm{x}_{6}, \mathrm{x}_{7}$ and $\mathrm{x}_{8}$ in Siemens Ltd. (Siemens) are 0.3041, 0.6304, 0.1843, 36.074, 0.6281, 175.92, 1.5298 and 1.0587 respectively. The ratio $x_{6}(175.92)$ represented the highest score whereas the ratio $\mathrm{x}_{1}(0.3041)$ represented the lowest. The total average score of Siemens Ltd. is 216.33. The credit score of Siemens Ltd. is 27.042.

Table 13

Risk Description Model - Ratio Measurement(Siemens)

\begin{tabular}{ccc}
\hline RATIOS & DESCRIPTION & AVG SCORES \\
\hline X1 & NP/CE & 0.3041 \\
X2 & NTA/TL & 0.6304 \\
X3 & NP/CL & 0.1843 \\
X4 & NWC/CR.EXPOSU & 36.074 \\
X5 & E/CL+CR.EXPOSU & 0.6281 \\
X6 NA/CR.EXPOSU & 175.92 \\
X7 & TA/TL+CR.EXPOSU & 1.5298 \\
X8 & NP+D/CD & 1.0587 \\
TOTAL AVG SCORES & & 216.33 \\
CREDIT SCORES(CS) & 27.042 \\
\hline
\end{tabular}

Therefore, table 9, 10, 11, 12 and 13 reveals that from current profitability point of view Hawkins is the best whereas from cumulative profitability's view point Havells is the best. On the other hand, in respect of debt paying capacity, Khaitan is the best. The score shows that under consumer durables sector the highest credit scores obtained by Khaitan and it followed by Havells, Siemens, Hawkins and Voltas in that order. The score plotted in Fig. $\mathbf{3}$ shows that under consumer durables sector the highest credit scores obtained by Khaitan and it followed by Havells, Siemens, Hawkins and Voltas in that order.

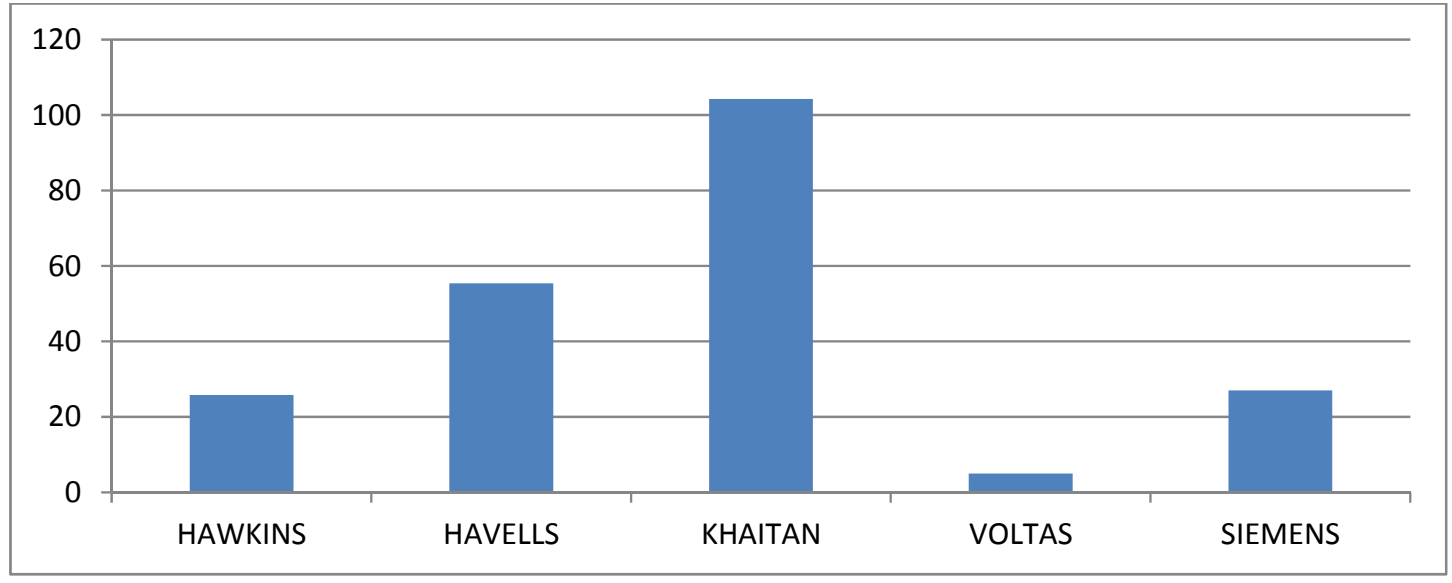

Fig. 3. Credit Scores of Consumer Durable Sector

In Table 14, sector wise ranking and ranking on the basis of companies as a whole have been done regarding their credit score. In depth analysis of credit score it is revealed that the credit score of selected companies is mainly influenced by two ratios, liquidity ratio (x4) and comfort margin(x6). Table 14 reveals that in Consumer Durables sector the ratio $\mathrm{x}_{4}$ in Hawkins , Havells, Khaitan, Voltas and Siemens are 71.23, 72.376, 86.38, (-)52.5, 36.07 respectively. On the other hand, ratio x6 in Hawkins, Havells, Khaitan, Voltas and Siemens are 129.0, 360.8, 735.5, 89.372 and 175.9 respectively. In Khaitan ratio $\mathrm{x}_{4}$ and ratio $\mathrm{x}_{6}$ is the highest. Such ratio helped the Khaitan to occupy the first position in Consumer Durables sector. 
Table 14

Ranking on the basis of Credit Scores of the Selected Companies of Consumer Durable Sector

\begin{tabular}{|c|c|c|c|c|c|}
\hline \multirow{2}{*}{ RATIOS } & \multicolumn{5}{|c|}{ COMPANIES } \\
\hline & HAWKINS & HAVELLS & KHAITAN & VOLTAS & SIEMENS \\
\hline $\mathrm{X} 1$ & 0.307 & 0.215 & 0.034 & 0.268 & 0.304 \\
\hline $\mathrm{X} 2$ & 0.687 & 1.549 & 3.139 & 0.261 & 0.63 \\
\hline X3 & 0.371 & 0.522 & 0.12 & 0.084 & 0.184 \\
\hline $\mathrm{X} 4$ & 71.23 & 72.76 & 86.38 & -52.5 & 36.07 \\
\hline $\mathrm{X} 5$ & 0.683 & 1.536 & 3.17 & 0.289 & 0.628 \\
\hline $\mathrm{X} 6$ & 129 & 360.8 & 735.5 & 89.72 & 175.9 \\
\hline $\mathrm{X} 7$ & 2.183 & 3.172 & 5.049 & 1.24 & 1.53 \\
\hline $\mathrm{X} 8$ & 2.161 & 2.534 & 0.822 & 0.48 & 1.059 \\
\hline TOTAL AVG SCORES & 206.7 & 443.1 & 834.2 & 39.88 & 216.3 \\
\hline CREDIT SCORES(CS) & 25.83 & 55.38 & 104.3 & 4.985 & 27.04 \\
\hline RANK & 4 & 2 & 1 & 5 & 3 \\
\hline
\end{tabular}

In depth analysis of the individual company's credit performance on the basis of credit score table indicates that liquidity ratio $\left(\mathrm{x}_{4}\right)$ i.e. the ratio of Normalized Working Capital to Credit Exposure is highly affected by percentage of Current Liabilities to Current Assets and percentage of Cash to Current Assets.It is found from table-15 that the liquidity ratio $\left(\mathrm{x}_{4}\right)$ as per our model in Hawkins is 71.23 whereas its current liabilities consist of $47.86 \%$ of current assets and at the same time cash occupied $10.56 \%$ of current assets. The liquidity ratio ( $\left.\mathrm{x}_{4}\right)$ as per our model in Havells is 72.75 whereas its current liabilities consist of $53.42 \%$ of current assets and at the same time cash occupied $6 \%$ of current assets. Similarly, the liquidity ratio ( $\left.\mathrm{x}_{4}\right)$ as per our model in Khaitan is 86.38 whereas its current liabilities consist of $60.15 \%$ of current assets and at the same time cash occupied 3.58\% of current assets.

The liquidity ratio ( $\left.\mathrm{x}_{4}\right)$ as per our model in Voltas is (-) 52.45 whereas its current liabilities consist of $81.59 \%$ of current assets and at the same time cash occupied $0.14 \%$ of current assets. Similarly, the liquidity ratio ( $\left.\mathrm{x}_{4}\right)$ as per our model in Siemens is 36.07 whereas its current liabilities consist of 71.27 $\%$ of current assets and at the same time cash occupied $21.20 \%$ of current assets.

\section{Table 15}

Analysis of Liquidity position of Consumer Durable Sector

\begin{tabular}{clccccc}
\hline CONSUMER DURABLES INDUSTRIES & \multicolumn{1}{c}{ CA } & CL & $\begin{array}{c}\text { AVG CASH } \\
\text { as \% OF CA }\end{array}$ & $\begin{array}{c}\text { CL \% } \\
\text { OF CA }\end{array}$ & $\begin{array}{c}\text { NWC/ } \\
\text { CREDIT EXPOSURE }\end{array}$ \\
\hline HAWKINS & 64.397 & 29.828 & 0.105657 & 0.47867200 & 71.22778459 \\
HAVELLS & 394.295 & 248.49 & 0.060004 & 0.53424062 & 72.7575355 \\
KHAITAN & 40.147 & 24.419 & 0.035881 & 0.60151173 & 86.38482057 \\
VOLTAS & 2456.711 & 2055.7 & 0.001448 & 0.81593705 & -52.45745207 \\
SIEMENS & 3299.805 & 2205.6 & 0.212013 & 0.71278214 & 36.07350993 \\
\hline
\end{tabular}

Hence, Table 15 exhibits that the liquidity ratio of Voltas is (-) 52.45. It is because in Voltas current liabilities consists higher portion of current assets and lower portion of cash. In other companies of Consumer durables sector where liquidity ratio is sound but higher portion of current liabilities on current assets is compensated by moderate cash balance.

Coefficient of Correlation is the measurement of degree of association between two variables. A positive value of ' $r$ ' indicated high values of one variable are generally associated with the high values of other variables and low values with low values. In this study multiple correlation technique among Cash as a \% of CA, CL as a \% of CA and NWC/Credit Exposure has been applied. To test the significance of such coefficient, 't' test has been used.

It has been found from Table-16 that in Consumer durables sector the correlation coefficient between cash as a percent of current assets and liquidity ratio ( $\mathrm{x} 4$ ) depicted a very low positive correlation, which is 0.261 , statistically insignificant. On the other hand, the correlation coefficient between current liabilities as a percent of current assets and liquidity (x4) revealed a high degree of negative correlation (-) 0.868 which is also statistically not significant. 
It also supported the theoretical principle that higher the current liabilities as a percent of current assets lower the liquidity ( $\left.\mathrm{x}_{4}\right)$. The correlation analysis in table-16 exhibits that cash as a percent of current assets and current liabilities as percent of current assets has a low degree of negative correlation (-) 0.098 which is statistically insignificant.

Table 16

Correlation Analysis of Consumer Durable Sector

\begin{tabular}{|c|c|c|c|c|}
\hline & & CASH OF CA & CL OF CA & $\begin{array}{c}\text { NWC OF CR } \\
\text { EXP }\end{array}$ \\
\hline \multirow[t]{3}{*}{ CASH OF CA } & Pearson Correlation & 1 & -0.098 & 0.261 \\
\hline & Sig. (2-tailed) & & 0.875 & 0.671 \\
\hline & $\mathrm{N}$ & 5 & 5 & 5 \\
\hline \multirow[t]{3}{*}{ CL OF CA } & Pearson Correlation & -0.098 & 1 & -0.868 \\
\hline & Sig. (2-tailed) & 0.875 & & 0.057 \\
\hline & $\mathrm{N}$ & 5 & 5 & 5 \\
\hline \multirow[t]{3}{*}{ NWC OF CR EXP } & Pearson Correlation & 0.261 & -0.868 & 1 \\
\hline & Sig. (2-tailed) & 0.671 & 0.057 & \\
\hline & $\mathrm{N}$ & 5 & 5 & 5 \\
\hline
\end{tabular}

\section{Conclusion}

Liquidity management deals with the management of current assets and current liabilities. Its main objective is to maintain current assets in such a way that it can meet the current liabilities timely. Many firms take the advantage of external financing due to the difficulty in paying its short-term debt. But the firm cannot collect such external financing easily, particularly in case of small firms. External financing is the costly. So, the efficient liquidity management of the company helps its long-term prosperity and healthy bottom lines and more specifically to make the company remain solvent.

Cash Conversion Cycle (CCC) is such a useful technique by which we can easily and quickly assess the liquidity of the firm. It invariably measures the time lag between cash payments for purchase of inventories and collection of receivables from customers. CCC is a dynamic measure of continuous liquidity management, which comprises both balance sheet and income statement data with time dimension.

An individual firm's CCC is helpful but from industries stand point it is crucial for a company to evaluate its performance regarding CCC and assess opportunities for improvement because the length of CCC may differ from industry to industry. From the liquidity view point Khaitan is the best. But, only in case of Siemens the relationship between CCC and ITR, CCC and CR, CCC and DTR, CCC and Debtors more than six months and CCC and CTR is theoretically sound. Out of which some factors positively and some factors negatively influenced the CCC of all the companies selected in this study.

From the five companies from Consumer Durable sector Siemens maintained higher level of cash throughout the study period and it helped the company to improve its liquidity position. From the point of view of average and consistency aspect together, Siemens and Voltas occupied the first rank. The correlation coefficients between ACH and DFL, ACH and Size of the Organization and ACH and Investment of most of the companies are positive. The impact of DFL on ACH and Investment on ACH of most of the companies is negative, whereas the impact of Size of the organization on ACH of most of the companies is positive.

Credit score signifies the credit worthiness of the company. Higher CS signifies better credit worthiness and vice-versa. Higher credit worthiness gives the opportunity to the company for late payment and late payment increases the deferral period. It again decreases the cash conversion cycle. Lower CCC represents less requirement of working capital. So liquid cash are not blocked in other types of current assets, it can invest in some profitable project to enhance profit. Hence good credit worthiness indirectly increases the profitability of the organization. From another point of view credit worthiness helps the company for achieving higher debtors' turnover. As the credit manager takes the decision of granting 
credit before the commencement of sales then it helps the organization to take decision regarding its future investment projects. It helps the management to know how and when money should be collected and such information protect the company to borrow funds for investing future profitable projects. It also minimizes the CCC of the organization which indirectly increases the profit of the organization.

In this study, we observed that from the view point of average and consistency of CCC, Khaitan was the best whereas consistency as cash as a \% of total assets Khaitan was also ranked first. In addition, in terms of the credit score point of view, Khaitan was the best. It signifies that due to higher credit score the said company managed to decrease its CCC and consistency in holding cash of the company was sound. Investment of Khaitan was negatively influenced the ACH. It means the company invested its unused fund to some profitable project to increase profitability. Next to Khaitan, the same conclusion can be drawn in case of Siemens.

\section{References}

Bari, R. R. (Ed.). (1981). Selected Readings in Cash Management. Triveni Publications.

Bradley, J. F. (1974). Administrative financial management. Dryden Press.

Brandt, L. K. (1965). Business finance: a management approach. Prentice-Hall.

Chiou, J. R., Cheng, L., \& Wu, H. W. (2006). The determinants of working capital management. Journal of American Academy of Business, 10(1), 149-155.

Clarkson, G. P., Elliott, B. J., \& Johnson, A. (1972). Managing Money and Finance. Gower Press.

Cohen, J. B., \& Robbins, S. M. (1966). The Financial Manager: Basic Aspects of Financial Administration. Harper \& Row.

Coyle, B. (2000). Cash Flow Control. Global Professional Publishing.

Dittmar, A., \& Mahrt-Smith, J. (2007). Corporate governance and the value of cash holdings. Journal of Financial Economics, 83(3), 599-634.

Driscoll, M. C. (1983). Cash Management: Corporate Strategies for Profit. Wiley.

Emery, G. W. (1987). An optimal financial response to variable demand. Journal of Financial and Quantitative Analysis, 22(02), 209-225.

Farris II, M. T., Hutchison, P. D., \& Hasty, R. W. (2011). Using cash-to-cash to benchmark service industry performance. Journal of Applied Business Research (JABR), 21(2).

Fazzari, S. M., \& Petersen, B. C. (1993). Working capital and fixed investment: new evidence on financing constraints. The RAND Journal of Economics, 328-342.

Ferreira, M. A., \& Vilela, A. S. (2004). Why do firms hold cash? Evidence from EMU countries. European Financial Management, 10(2), 295-319.

Guney, Y., Ozkan, A., \& Ozkan, N. (2007). International evidence on the non-linear impact of leverage on corporate cash holdings. Journal of Multinational Financial Management, 17(1), 45-60.

Jensen, M. C. (1986). Agency costs of free cash flow, corporate finance, and takeovers. The American Economic Review, 323-329.

Jose, M. L., Lancaster, C., \& Stevens, J. L. (1996). Corporate returns and cash conversion cycles. Journal of Economics and Finance, 20(1), 33-46.

Kalcheva, I., \& Lins, K. V. (2007). International evidence on cash holdings and expected managerial agency problems. Review of Financial Studies, 20(4), 1087-1112.

Keynes, J. M. (2006). General Theory of Employment, Interest and Money. Atlantic Publishers \& Dist.

Kim, C. S., Mauer, D. C., \& Sherman, A. E. (1998). The determinants of corporate liquidity: Theory and evidence. Journal of Financial and Quantitative Analysis, 33(03), 335-359.

Koen, M., \& Oberholster, J. (1999). Analysis and Interpretation of Financial Statements. Juta and Company Ltd.

Moss, J. D. \& Stine, B. (1993). Cash conversion cycle and firm size: A study of retail firms, Managerial Finance, 19(8), 25-34. 
Myers, S. C. (1977). Determinants of corporate borrowing. Journal of financial economics, 5(2), 147175.

Myers, S. C., \& Majluf, N. S. (1984). Corporate financing and investment decisions when firms have information that investors do not have. Journal of financial economics, 13(2), 187-221.

Nunn, K. P. (1981). The strategic determinants of working capital: A product-line perspective. Journal of Financial Research, 4(3), 207-219.

Opler, T., Pinkowitz, L., Stulz, R., \& Williamson, R. (1999). The determinants and implications of corporate cash holdings. Journal of Financial Economics, 52(1), 3-46.

Ortín-Ángel, P., \& Prior, D. (2004). Accounting Turnover Ratios and Cash Conversion Cycle. Problems and Perspectives in Management, 1, 189-205.

Uyar, A. (2009). The relationship of cash conversion cycle with firm size and profitability: an empirical investigation in Turkey. International Research Journal of Finance and Economics, 24(2), 186-193.

Pandey, I. M. (1999). Financial Management-Vikas Publishing House Pvt. Ltd-.

Petersen, M. A., \& Rajan, R. G. (1997). Trade credit: theories and evidence. Review of Financial Studies, 10(3), 661-691.

Solomon, E., \& Pringle, J. J. (1981). An Introduction to Financial Management. Scott, Foresman.

Van Horne, J. C. (1968). Financial Management and Policy (pp. 254-71). Prentice-Hall.

Walker, D. A. (1991). An empirical analysis of financing the small firm. In Advances in small business finance (pp. 47-61). Springer Netherlands. 